\title{
ANALISIS LOYALITAS PELANGGAN MELALUI KUALITAS PRODUK, HARGA, PELAYANAN DAN KEPUASAN PADA TOKO OUTLET BIRU YOGYAKARTA
}

\author{
Elly Kusumawati \\ kusuma.elly0408@gmail.com \\ Universitas Ahmad Dahlan \\ Fitroh Adhilla \\ fitauad@yahoo.com \\ Universitas Ahmad Dahlan
}

\begin{abstract}
ABSTRAK
This study aims to analyze loyalty analysis customers through product quality, price, service and satisfaction in stores Yogyakarta Blue Outlet. The independent variable used in the study this is roduct quality, price, service and satisfaction. The dependent used is customer loyalty. The population in this study are all consumers who have visited and make purchases at Yogyakarta Blue Outlet stores. Based on the method purposive sampling was obtained by 62 respondents. The type of data usedis primary data. Data obtained by the method of distributing questionnaires which is distributed directly to respondents who meet the criteria needed. Validity and realibility test of the questionnaire which was used as a tool showed that the questionnare is valid and reliable for use. Based on the results of data analysis, there is an influence on product quality to customer satisfaction with a significant value of $0.031<0.05$ means the first hypothesis is accepted, there is the effect of price on satisfaction consumers with a significant value of $0.016<0.05$ means that the second hypothesis is accepted, there is an influence of service on customer satisfaction with value significant $0,000<0.05$ means that the third hypothesis is accepted, there is an influence satisfaction with customer loyalty with a significant value of $0.004<0.05$ means the fourth hypothesis is accepted. With the Adjusted R square value at stage 1 namely 0.672 and in stage II is 0.118 .
\end{abstract}

Keywords: loyalty customer, product quality, price, service and satisfaction.

\begin{tabular}{l}
\hline \multicolumn{4}{c}{ PENDAHULUAN } \\
\hline \multicolumn{4}{c}{ puatu perusahaan } & dalam \\
aktivitasnya menjadi hal wajib, untuk \\
mengelola jasa dengan baik, sehingga \\
secara prinsip menemukan manajemen \\
profesional pada pemasaran, operasi \\
maupun sumber daya manusia. Integrasi \\
unsur-unsur tersebut akan menjadi kunci \\
keberhasilan perusahaan untuk \\
meningkatkan kinerjanya. Kualitas \\
merupakan titik awal dalam merebut \\
pangsa pasar, sehingga tingkat kepuasan \\
tidak hanya perlu dipertahankan tetapi \\
juga harus ditingkatkan untuk
\end{tabular}

menghadapi per saingan yang semakin ketat. Oleh karena itu perusahaan di tuntut untuk mampu menggerakan, mengatur dan mengkoordinasikan kegiatan dari berbagai kelompok tenaga profesional, semi profesional dan tenaga non profesional yang ada sehingga dapat mencapai tujuan yang telah direncanakan (Saputro, 2013).

Konsumen tidak hanya berperan sebagai pembeli dari sebuah produk atau jasa yang di tawarkan oleh sebuah perusahaan, namun konsumen juga berperan sebagai sumber penghasilan tetap, apabila konsumen melakukan pembelian yang berulang dan rutin, serta 
merekomendasikan produk ataupun jasa yang ditawarkan oleh perusahaan kepada teman, keluarga maupun kerabatnya berarti konsumen tersebut loyal (Saputro, 2013).

Loyalitas konsumen adalah sikap menyenangi terhadap suatu merek yang dipresentasikan dalam pembelian yang konsisten terhadap merek itu sepanjang waktu (Saputro, 2013). Apabila konsumen loyal terhadap merek maka akan berusaha menggunakan atau mengkonsumsi produk merek tersebut sepanjang waktu. Seorang konsumen yang sangat loyal kepada suatu merek tidak akan dengan mudah memindahkan pembelian ke merek lain, apapun yang terjadi dengan merek tersebut (Saputro, 2013).

Kepuasan konsumen menurut hal yang diungkapkan Saidani dan Arifin (2012) mendefinisikan kepuasan pelanggan sebagai respon pelanggan terhadap evaluasi ketidaksesuaian yang dirasakan antara harapan dan kinerja aktual jasa. Terdapat tiga dimensi dalam mengukur kepuasan pelanggan secara universal yaitu:

1. Attributes related to product, yaitu dimensi kepuasan yang berkaitan dengan atribut dari produk seperti penetapan nilai yang didapatkan dengan harga, kemampuan produk menentukan kepuasan, benefit dari produk tersebut.

2. Attributes related to service, yaitu dimensi kepuasan yang berkaitan dengan atribut dari pelayanan misalnya dengan garansi yang dijanjikan, proses pemenuhan pelayanan atau pengiriman, dan proses penyelesaian masalah yang diberikan.

3. Attributes related to purchase, yaitu dimensi kepuasan yang berkaitan dengan atribut dari keputusan untuk membeli atau tidaknya dari produsen seperti kemudahan mendapat informasi, kesopanan karyawan dan juga pengaruh reputasi perusahaan.
Pada era globalisasi saat ini, perusahaan harus secara cermat dalam menetapkan harga pada setiap produknya, karena penetapan harga pada sebuah produk akan berdampak langsung terhadap tingkat permintaan produk tersebut. Bagi para konsumen, harga bukan hanya sekedar nilai tukar barang atau jasa, tetapi konsumen selalu mengharapkan adanya timbal balik yang sesuai antara manfaat produk yang akan mereka terima dengan pengorbanan yang mereka keluarkan. Harga merupakan sesuatu yang diserahkan dalam pertukaran untuk mendapatkan suatu barang maupun jasa. Banyak cara yang bisa dicapai oleh perusahaan untuk meningkatkan kepuasan konsumen, misalnya dengan memperhatikan faktor harga. Pada umumnya konsumen akan cenderung memilih perusahaan yang menawarkan produknya dengan harga yang relatif murah (Amanah, 2010).

Banyak faktor yang dapat mempengaruhi loyalitas konsumen. faktor yang dapat mempengaruhi loyalitas konsumen adalah kualitas, produk, dan harga. Saputro (2013) salah satu faktor yang dapat mempengaruhi loyalitas konsumen adalah kualitas pelayanan.Kualitas pelayanan merupakan suatu pernyataan tentang sikap, hubungan yang dihasilkan dari perbandingan antara ekspetasi (harapan) dengan kinerja (hasil) (Saputro,2013). Ekuitas merek adalah seperangkat harta dan hutang merek yang terkait dengan suatu merek, nama, symbol, yang mampu menambah atau mengurangi nilai yang diberikan oleh suatu produk atau jasa baik pada perusahaan maupun pada pelangganApabila konsumen loyal terhadap merek, maka akan berusaha menggunakan atau mengkonsumsi produk tersebut sepanjang waktu.

Toko Outlet Biru adalah adalah Outlet yang menyediakan berbagai produk mulai dari baju, celana, sepatu, tas, topi. Bukan hanya untuk laki-laki tetapi untuk wanita juga tersedia. Outlet yang terkenal 
di kota Yogyakarta ini menjual produk dari yang asli hingga palsu (tiruan) toko Outlet Biru juga mempunyai banyak pelanggan da ri berbagai kalangan masyarakat terutama untuk pelajar dan mahasiswa. Agar berhasil dalam membangun loyalitas pelanggan, toko Outlet Biru harus menjaring konsumen sebanyak-banyaknya dengan kata lain perusahaan harus dapat menarik minat beli ulang konsumen agar konsumen tersebut memberitahukan kepada temantemannya dan menjadi pelanggan yang loyal berbelanja di toko Outlet Biru Yogyakarta.

Tujuan penelitian ini adalah: 1) untuk mengetahui pengaruh positif kualitas produk terhadap kepuasan konsumen, 2) untuk mengetahui pengaruh positif harga terhadap kepuasan konsumen, 3) untuk mengetahui pengaruh positif pelayanan terhadap kepuasan konsumen dan 4) untuk mengetahui kepuasan konsumen terhadap loyalitas konsumen.

\section{REVIEW LITERATUR DAN HIPOTESIS}

\section{Landasan Teori}

1. Manajemen

Manajemen adalah suatu proses atau kerangka kerja yang melibatkan bimbingan atau pengarahan suatu kelompok orang-orang ke arah tujuantujuan organisasional atau maksudmaksud yang nyata (Nuraini, 2018). Manajemen juga adalah suatu ilmu pengetahuan maupun seni. Seni adalah bagaimana mencapai hasil yang di inginkan atau dalam kata lain seni adalah kecakapan yang diperoleh dari pengalaman, pengamatan, dan pelajaran serta kemampuan untuk menggunakan pengetahuan manajemen.

\section{Perilaku Konsumen}

Menurut Olson (2013) prilaku konsumen sebagai dinamika interaksi antara pengaruh dan kesadaran, perilaku dan lingkungan dimana manusia melakukan pertukaran aspekaspek kehidupan. Dengan kata lain, perilaku konsumen melibatkan pemikiran dan perasaan yang meeraka alami serta tindakan yang mereka lakukan dalam proses konsumsi. Mencakup segala hal pada lingkungan yang mempengaruhi pemikiran, perasaan, dan tidakan. Termasuk komentar konsumen, iklan, informarsi harga, pengepakan, penampilan produk, dan lainnya.

3. Loyalitas Pelanggan

Konsumen yang loyal pada umumnya akan melanjutkan pembelian merek tersebut walaupun dihadapkan dengan banyak alternatif merek produk pesaing yang menawarkan karakteristik produk yang lebih unggul di pandang dari berbagai sudut atributnya bila banyak konsumen dari suatu merek masuk dalam kategori ini, berarti merek tersebut memiliki ekuitas merek yang kuat. Ekuitas merek adalah seperangkat harta dan hutang merek yang terkait dengan suatu merek, nama, simbol, yang mampu menambah atau mengurangi nilai yang diberikan oleh suatu produk atau jasa baik pada perusahaan maupun pada pelanggan (Saputro, 2013).

Konsumen yang tidak loyal kepada suatu merek, pada saat melakukan pembelian merek tersebut, pada umumnya tidak didasarkan karena ketertarikan mereka pada merekn ya, tetapi lebih didasarkan pada karakteristik produk, harga dan kenyamanan pemakaiannya ataupun berbagai atribut lain yang ditawarkan oleh merek produk alternatif. Bila sebagian konsumen dari suatu merek termasuk dalam kategori ini, berarti kemungkinan ekuitas merek tersebut adalah lemah (Saputro, 2013). 
4. Kualitas Produk

Amanah (2010) menjelaskan kualitas produk adalah kemampuan suatu produk untuk melakukan Fungsifungsinya; kemampuan itu meliputi daya tahan, kehandalan, ketelitian yang dihasilkan, kemudahan dioperasikan dan diperbaiki, dan atribut lain yang berharga pada produk secara keseluruhan

\section{Harga}

Menurut Amanah (2010) harga adalah sejumlah uang (ditambah beberapa produk kalau mungkin) yang dibutuhkan untuk mendapatkan sejumlah kombinasi dari produk dan pelayanannya.

6. Kualitas Pelayanan

Menurut Saidani dan Arifin (2012) kualitas pelayanan adalah kualitas jasa yang merupakan sesuatu yang di persepsikan oleh pelanggan. Pelanggan akan menilai kualitas sebuah jasa yang dirasakan berdasarkan apa yang mereka deskripsikan dalam benak mereka. Pelanggan akan beralih ke penyedia jasa lain yang lebih mampu memahami kebutuhan spesifik pelanggan dan memberikan layanan yang lebih baik.

7. Kepuasan

Menurut Amanah (2010) kepuasan adalah perasaan senang atau kecewa seseorang yang muncul setelah membandingkan persepsi/kesannya terhadap kinerja (atau hasil) suatu produk dan harapan-harapannya.

\section{Hipotesis}

H1: Kualitas produk berpengaruh positif terhadap kepuasaan konsumen.

$\mathrm{H} 2$ : Harga berpengaruh positif terhadap kepuasaan konsumen.

H3: Kualitas pelayanan berpengaruh positif terhadap kepuasaan konsumen.
H4: Kepuasan konsumen berpengaruh positif terhadap loyalitas konsumen.

\section{METODE PENELITIAN}

\section{Populasi dan Sampel}

Sugiyono (2010) mendefinisikan populasi adalah wilayah generalisasi yang terdiri atas obyek ataupun subyek yang mempunyai kualitas dan karakteristik tertentu yang ditetapkan oleh peneliti untuk dipelajari kemudian ditarik kesimpulan. Populasi dalam penelitian ini adalah seluruh konsumen yang pernah berkunjung dan melakukan pembelian di toko Outlet Biru, dengan asumsi jumlah dalam penelitian ini bahwa jumlah populasi tidak terbatas.

Sampel adalah suatu bagian dari jumlah dan karakteristik yang dimiliki oleh populasi. Bila populasi besar tidak mungkin mempelajari semua yang ada pada populasi karena terdapat beberapa keterbatasan maka dapat menggunakan sampel yang diambil dari populasi (Sugiyono, 2010). Sampel dalam penelitian ini adalah pembeli dan pengguna produk outlet biru.

\section{Teknik Pengumpulan Data}

Metode angket atau kuesioner adalah teknik pengumpulan data yang dilakukan dengan cara memberi seperangkat pertanyaan tertulis kepada responden untuk di jawabnya (Sugiyono, 2014). Daftar pertanyaan dalam kuisoner ini harus sesuai dengan permasalahan yang diteliti, dan memperoleh data berkaitan dengan membangun loyalitas pelanggan melalui kualitas produk, harga, dan pelayanan melalui mediasi kepuasan pada toko Outlet Biru. 


\section{Definisi Operasional}

1. Variabel Dependen

Variabel dependen adalah variabel yang menjadi pusat perhatian penelitian (Nuraini, 2018). Variabel dependen dalam penelitian ini adalah loyalitas konsumen. Adapun indikator dari loyalitas konsumen menurut Saputro (2013) adalah sebagai berikut:

a. Percaya terhadap produk perusahaan.

b. Tidak terpengaruh terhadap produk perusahaan lain.

c. Merekomendasikan kepada orang lain.

d. Akan tetap membeli meskipun pesaing lebih bagus.

2. Variabel Independen

Variabel independen dalam penelitian ini terdiri dari kualitas produk, harga, pelayanan dan kepuasan.

\section{Uji Instrumen}

\section{Uji Validitas}

Menurut Sugiono (2010) uji validitas adalah uji statistik yang digunakan untuk menentukan seberapa valid suatu item pertanyaan mengukur variabel yang diteliti. Itemitem terebut mampu memberikan dukungan dalam mengungkap apa yang ingin di ungkap atau dinyatakan valid. Kuesioner dikatakan valid jika pertanyaan pada kuesioner mampu mengungkapkan sesuatu yang akan diukur oleh kuesioner terssebut. Alat uji validitas yang diigunakan dalam penelitian ini adalah Confirmatory Factor Analisis (CFA) dengan nilai faktor loading lebih besar dari 0,5 dan mampu menjelaskan variabel maka dikatakan valid, untuk memudahkan dalam melakukan uji validitas, maka digunakan analisis faktor yang ada program komputer SPSS 21.

\section{Uji Reliabilitas}

Sugiyono (2014) instrumen yang reliabel adalah yang bila digunakan beberapa kali untuk mengukur objek yang sama akan mendatangkan data yang sama. Dengan menggunakan instrumen yang valid dan reliabel dalam pengumpulan data, maka diharapkan hasil penelitian akan menjadi valid dan reliabel. Dikatakan reliabel apabila Cronbach Alpha diatas 0,6. Jadi instrumen yang valid dan reliabel merupakan syarat mutlak untuk mendapatkan hasil penelitian yang valid dan reliabel.

\section{Teknik Analisis Data}

1. Analisis Regresi Linier Berganda

$$
\text { Analisis regresi berganda }
$$
digunakan untuk mengetahui seberapa besar pengaruh antara kualitas produk (X1), harga (X2) , Kualitas Pelayanan (X3) dan kepuasan (Z) terhadap loyalitas konsumen (Y). selain itu untuk mengetahui sejauh mana besarnya pengaruh antara variabel bebas dan variabel terikat.

a. Persamaan regresi linear berganda model I

Teknik regresi digunakan untuk melakukan prediksi seberapa jauh nilai variabel independen $\mathrm{X} 1, \mathrm{X} 2$, $\mathrm{X} 3$ mempengaruhi nilai variabel Z. Berikut adalah persamaan regresi berganda model I:

$\mathrm{Z}=\mathrm{a}+\mathrm{b} 1 \mathrm{x} 1+\mathrm{b} 2 \times 2+\mathrm{b} 3 \times 3$

b. Persamaan linear berganda model II

Teknik regresi digunakan untuk mengetahui seberapa jauh nilai variabel $\mathrm{Z}$ terhadap variabel dependen Y. Berikut adalah 
persamaan regresi berganda model II: $\mathrm{Y}=\mathrm{a}+\mathrm{BZ}$

\section{Uji Parsial (Uji T)}

Uji $\mathrm{T}$ digunakan untuk menguji pengaruh variabel independen secara parsial terhadap variabel dependen. Pengujian ini dilakukan dengan uji $\mathrm{t}$ pada tingkat keyakinan 95\% dengan ketentuan sebagai berikut:

Merumuskan hipotesis:

$\mathrm{X} 1$ : Kualitas produk

H0: Tidak terdapat pengaruh positif kualitas produk terhadap kepuasan konsumen

Ha: Terdapat pengaruh positif kualitas produk terhadap kepuasan konsumen

X2: Harga

H0: Tidak terdapat pengaruh positif harga terhadap kepuasan konsumen

Ha: Terdapat pengaruh positif harga terhadap kepuasan konsumen

X3: Kualitas pelayanan

H0: Tidak terdapat pengaruh positif kualitas pelayanan terhadap kepuasan konsumen

Ha: Terdapat pengaruh positif kualitas pelayanan terhadap kepuasan konsumen

Z: Kepuasan konsumen

H0: Tidak terdapat pengaruh positif kepuasan konsumen terhadap loyalitas pelanggan

Ha: Terdapat pengaruh positif kepuasan konsumen terhadap loyalitas pelanggan

Pengambilan keputusan dengan tingkat signifikansi (a) $=0,05 \mathrm{di}$ tentukan atas dasar pengambilan keputusan dengan cara sebagai berikut : 1) Jika tingkat signifikansi $>0,05$ maka H0 diterima
2) Jika tingkat signifikansi $<0,05$ maka H0 ditolak

3. Analisis Koefisien Determinasi

Koefisien determinasi

digunakan untuk mengetahui sampai seberapa besar presentase variasi variabel bebas pada model dapat diterangkan oleh terikat. Koefisien determinasi (R2) dinyatakan dalam presentase yang nilainya berkisar antara $0<\mathrm{R} 2<1$. Nilai R2 yang kecil berarti kemampuan variabel-variabel independen dalam menjelaskan variasi satu berarti variabel-variabel independen memberikan haampir semua informasi yang dibutuhkan untuk memprediksi variasi variabel dependen.

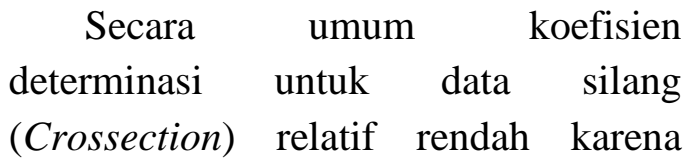
adanya variasi yang besar antara masing-masing pengamatan, sedangkan untuk data runtun waktu (Time series) biasanya mempunyai niilai koefisien determinasi yang tinggi.

\section{HASIL PENELITIAN DAN PEMBAHASAN}

\section{Hasil Analisis Responden}

Responden yang menjadi sampel dalam penelitian ini diklasifikasi berdasarkan usia, jenis kelamin, pekerjaan, dan penghasilan atau uang saku setiap bulan, dan tempat tinggal Yogyakarta. Berikut ini akan dibahas mengenai kondisi dari masingmasing klasifikasi responden: 
Jumlah responden menurut usia

\begin{tabular}{|l|l|l|l|}
\hline No. & Usia & Jumlah & Frekuensi (\%) \\
\hline 1. & $17-22$ tahun & 52 & $83,9 \%$ \\
\hline 2. & $23-28$ tahun & 9 & $14,5 \%$ \\
\hline 3. & $29-34$ tahun & 0 & $0 \%$ \\
\hline 4. & $35-40$ tahun & 1 & $1,6 \%$ \\
\hline & Total & 62 & $100 \%$ \\
\hline
\end{tabular}

Berdasarkan kuisioiner yang telah dibagikan kepada responden dapat diketahui bahwa jumlah sampel yang berusia 17-22 tahun sebanyak 52 responden $(83,9 \%)$, usia 23-28 tahun sebanyak 9 responden (14,5\%), usia 29-34 tahun sebanyak 0 responden $(0 \%)$, dan usia 35-40 tahun sebanyak 1 responden $(1,6 \%)$.

\section{Jumlah Responden Menurut Jenis Kelamin}

\begin{tabular}{|l|l|l|l|}
\hline No. & Jenis Kelamin & Jumlah & Frekluensi(\%) \\
\hline 1. & Laki-aki & 24 & $38,7 \%$ \\
\hline 2. & Perempuan & 38 & $61,3 \%$ \\
\hline & Total & 62 & $100 \%$ \\
\hline
\end{tabular}

Berdasarkan data diatas dapat disimpulkan bahwa responden terbesar berjenis kelamin perempuan yaitu sebanyak 38 responden (61,3\%), sedangkan responden laki-laki sebesar 24 responden $(38,7 \%)$.

Jumlah Responden profesi atau pekerjaan

\begin{tabular}{|l|l|l|l|}
\hline No. & Profesi atau pekerjaan & Jumlah & Frekuensi(\%) \\
\hline 1. & Pelajar/Mahasiswa & 56 & $90,3 \%$ \\
\hline 2. & Pegawai Swasta & 5 & $8,1 \%$ \\
\hline 3. & PNS & 0 & $0 \%$ \\
\hline 4. & Lain-lain & 1 & $1,6 \%$ \\
\hline & Total & 62 & $100 \%$ \\
\hline
\end{tabular}

Berdasarkan kuesioner yang telah dibagikan kepada responden dapat diketahui bahwa jumlah responden dengan profesi pelajar/mahasiswa sebanyak 56responden $(90,3 \%)$, responden dengan profesi pegawai swasta sebanyak 5 responden $(8,1 \%)$, responden dengan profesi PNS sebanyak 0 responden $(0 \%)$, sedangkan untuk responden dengan profesi lain-lain sebanyak 1 responden $(1,6 \%)$.

Jumlah Responden Menurut Penghasilan (uang saku) perbulan

\begin{tabular}{|l|l|l|l|}
\hline No. & Penghasilan (Uang saku) & Jumlah & Frekuensi (\%) \\
\hline 1. & 0-Rp1000.000 & 37 & $59,7 \%$ \\
\hline 2. & Rpl.100.000-Rp2.000.000 & 15 & $24,2 \%$ \\
\hline 3. & Rp2.100.000-Rp3.000.000 & 5 & $8,1 \%$ \\
\hline 4. & $>$ Rp3.100.000 & 5 & $8,1 \%$ \\
\hline & Total & 62 & $100 \%$ \\
\hline
\end{tabular}

Dari data diatas dapat disimpulkan bahwa sampel responden yang mempunyai penghasilan (uang saku) perbulan sebesar $0-$ Rp1000.000 adalah sebanyak 37 responden $(59,7 \%)$, sedangkan sampel responden yang mempunyai penghasilan (uang saku) perbulan sebesar Rp1.100.000Rp2.000.000 sebanyak 15 responden $(24,2 \%)$ dan merupakan responden terbesar, sampel responden yang mempunyai penghasilan (uang saku) perbulan sebesar Rp2.100.000Rp3.000.000 sebanyak 5 responden $(8,1 \%)$, dan sampel responden yang mempunyai penghasilan. 
Jumlah Responden tempat tinggal di Yogyakarta

\begin{tabular}{|l|l|l|l|}
\hline No. & Profesi atau pekerjaan & Jumlah & Frekuensi $(\%)$ \\
\hline 1. & Rumah sendiri & 12 & $19,4 \%$ \\
\hline 2. & Kontrakan & 10 & $16,1 \%$ \\
\hline 3. & Kost & 38 & $61,3 \%$ \\
\hline 4. & Lain-lain & 2 & $3,2 \%$ \\
\hline & Total & 62 & $100 \%$ \\
\hline
\end{tabular}

Dari data diatas dapat disimpulkan bahwa sampel responden yang tinggal di kontrakan sebanyak 12 responden $(19,4 \%)$, sedangkan sampel responden yang tinggal di kontrakan sebanyak 10 responden $(16,1 \%)$, untuk sampel responden yang tinggal di kost sebanyak 38 responden $(61,3 \%)$ dan merupakan responden terbesar, sampel responden yang tinggal di lain-lain sebanyak 2 responden $(3,2 \%)$.

\section{Hasil Penelitian}

1. Hasil Uji Validitas
a. Hasil Uji Validitas Loyalitas Konsumen (Y)

Uji validitas variabel Loyalitas Konsumen (Y) tahap 1

\begin{tabular}{|l|c|}
\hline & Component \\
\cline { 2 - 2 } & 1 \\
\hline LK 1 & 0,461 \\
\hline LK 2 & 0,866 \\
\hline LK 3 & 0,600 \\
\hline LK 4 & 0,765 \\
\hline
\end{tabular}

Tabel component matrix pada hasil output SPSS, terlihat sudah membentuk 1 komponen, namun terlihat bahwa indikator LK1 memiliki nilai $<0,5$ maka dengan demikian indikator tersebut yaitu pertanyaan nomer 1 dari variabel loyalitas konsumen dikeluarkan dari analisis karena dinyatakan tidak valid. Setelah penghapusan pertanyaan LKI maka diperoleh hasil komponen yang baru seperti berikut: Uji validitas variabel Loyalitas Konsumen (LK) tahap 2

\begin{tabular}{|l|c|}
\hline & Component \\
\cline { 2 - 2 } & 1 \\
\hline LK 2 & 0,861 \\
\hline LK 3 & 0,597 \\
\hline LK 4 & 0,836 \\
\hline
\end{tabular}

Tabel component matrix pada hasil output SPSS, terlihat sudah membentuk 1 komponen, nilainya lebih besar dari 0,5 yang artinya indikator LK 2, LK 3, LK 4. dinyatakan valid dan tidak terdapat hasil yang menunjukan angka negatif dalam suatu komponen

b. Hasil Uji Validitas Kualitas Produk (X1)

Uji Validitas Pertama Variabel Kualitas Produk (X1)

\begin{tabular}{|l|c|}
\hline & Component \\
\cline { 2 - 2 } & 1 \\
\hline KP.1 & 0,746 \\
\hline KP.2 & 0,848 \\
\hline KP.3 & 0,755 \\
\hline
\end{tabular}

Tabel component matrix pada hasil output SPSS, terlihat sudah membentuk 1 komponen dan nilainya lebih besar dari 0,5 yang artinya indikator KP.1, KP.2, KP 3. dinyatakan valid dan hanya menjelaskan faktor variabel kualitas produk. 
c. Hasil Uji Validitas Harga (X2)

Uji Validitas Pertama Variabel Harga

\begin{tabular}{|c|c|}
\hline & Component \\
\cline { 2 - 2 } & 1 \\
\hline H 1 & 0,746 \\
\hline H 2 & 0,799 \\
\hline H 3 & 0,774 \\
\hline
\end{tabular}

Tabel component matrix pada hasil output SPSS, terlihat sudah membentuk 1 komponen dan nilainya lebih besar dari 0,5 yang artinya indikator $\mathrm{H} 1, \mathrm{H} 2, \mathrm{H} 3$. dinyatakan valid dan hanya menjelaskan faktor variabel harga.

d. Hasil Uji Validitas Pelayanan (X3) Uji Validitas Pertama Variabel Pelayanan (X3)

\begin{tabular}{|c|c|}
\hline & Component \\
\cline { 2 - 3 } & 1 \\
\hline P 1 & 0,848 \\
\hline P 2 & 0,687 \\
\hline P 3 & 0,609 \\
\hline P 4 & 0,674 \\
\hline P 5 & 0,670 \\
\hline
\end{tabular}

Tabel component matrix pada hasil output SPSS, terlihat sudah membentuk 1 komponen dan nilainya lebih dari 0,5 yang artinya indikator P1, P2, P3, P4, P5 dinyatakan valid dan hanya menjelaskan faktor pelayanan. e. Hasil Uji Validitas Kepuasan (Z)

Uji Validitas Variabel Kepuasan (Z)

\begin{tabular}{|c|c|}
\hline & Component \\
\cline { 2 - 2 } & 1 \\
\hline $\mathrm{k} 1$ & 0,832 \\
\hline $\mathrm{k} 2$ & 0,859 \\
\hline $\mathrm{k} 3$ & 0,540 \\
\hline $\mathrm{K} 4$ & 0,785 \\
\hline
\end{tabular}

Tabel component matrix pada hasil output SPSS, terlihat sudah membentuk 1 komponen, yang artinya indikator $\mathrm{K} 1, \mathrm{~K} 2$, $\mathrm{K} 3$,K4. dinyatakan valid dan hanya menjelaskan faktor variabel kepuasan .

2. Hasil Uji Reliabilitas Hasil Uji Reliabilitas

\begin{tabular}{|l|l|l|l|}
\hline Variabel & $\begin{array}{l}\text { Cronbach's } \\
\text { alpha }\end{array}$ & a-batas & Keterangan \\
\hline Kualitas Produk (XI) & 0,653 & 0,60 & Reliabel \\
\hline Harga (X2) & 0,640 & 0,60 & Reliabel \\
\hline Pelayanan (X3) & 0,735 & 0,60 & Reliabel \\
\hline Kepuasan (Z) & 0,755 & 0,60 & Reliabel \\
\hline Loyalitas Konsumen (Y) & 0,628 & 0,60 & Reliabel \\
\hline
\end{tabular}

Dari tabel yang disajikan di atas, maka diketahui hasil uji reliabilitas dapat dijelaskan sebagai berikut:

a. Bahwa variabel kualitas produk (X1) memiliki nilai cronbach's alpha sebesar 0,653>0,60. Berdasarkan ketentuan diatas maka indikator-indikator dalam variabel produk dinyatakan reliabel.

b. Bahwa variabel harga (X2) memiliki nilai cronbach's alpha sebesar 0,640 
$>$ 0,60. Berdasarkan ketentuan diatas maka indikator-indikator dalam variabel harga dinyatakan reliabel.

c. Bahwa variabel pelayanan (X3) memiliki nilai cronbach's alpha sebesar $0,735>0,60$. Berdasarkan ketentuan diatas maka indikatorindikator dalam variabel lokasi dinyatakan reliabel.

d. Bahwa variabel kepuasan (Z) memiliki nilai cronbach's alpha sebesar $0,755>0,60$. Berdasarkan ketentuan diatas maka indikatorindikator dalam variabel kepuasan dinyatakan reliabel.

e. Bahwa variabel loyalitas konsumen (Y) memiliki nilai cronbach's alpha sebesar 0,628>0,60. Berdasarkan ketentuan diatas maka indikatorindikator dalam variabel loyalitas konsumen dinyatakan reliabel.

Berdasarkan hasil analisis di atas dapat ditarik kesimpulan bahwa masing-masing variabel baik variabel independen maupun variabel dependen semuanya dinyatakan reliabel dan layak untuk digunakan menjadi alat ukur kuisioner di dalam penelitian ini.

3. Hasil Analisis Regresi Berganda a. Analisis Regresi Berganda Model 1 Hasil Analisis Regresi Linier Berganda model I

\begin{tabular}{|l|l|l|}
\hline \multirow{2}{*}{ Model } & $\begin{array}{l}\text { Unstandarized } \\
\text { Coefficients }\end{array}$ & \multirow{2}{*}{ Sig. } \\
\cline { 2 - 2 } & B & \\
\hline (konstanta) & 0,677 & 0,003 \\
\hline X1 & 0,156 & 0,031 \\
\hline X2 & 0,233 & 0,016 \\
\hline X3 & 0,416 & 0,000 \\
\hline
\end{tabular}

Dari tabel yang telah disajikan sebelumnya, maka hasil sampel yang dapat diperoleh dimasukan kedalam persamaan regresi sebagai berikut:

$\mathrm{Z}=\mathrm{a}+\mathrm{b} 1 \mathrm{X} 1+\mathrm{b} 2 \mathrm{X} 2+\mathrm{b} 3 \mathrm{X} 3$

Diketahui:

$Z=0,677+0,156+0,233+0,416$

Dari hasil persamaan regresi linier berganda tersebut, dapat diinteprestasikan sebagai berikut: $a=0,677$ ialah konstanta, jika nilai $\mathrm{X} 1, \mathrm{X} 2, \mathrm{X} 3$ dianggap 0 maka nilai kepuasan konsumen akan menurun sebesar 0,677 .

$\mathrm{b} 1=0,156$ artinya variabel kualitas produk berpengaruh positif artinya terjadi hubungan positif antara kualitas produk (X1) dan kepuasan konsumen semakin besar kualitas produk semakin meningkat kepuasan konsumen. Koefisien regresi variabel kualitas produk (X1) sebesar 0,156 . Artinya jika variabel lain nilainya tetap dan variabel kualitas produk (X1) naik 1 satuan maka kepuasan meningkat 0,156 .

$\mathrm{b} 2=0,233$ artinya variabel harga (X2) berpengaruh positif artinya terjadi hubungan positif antara harga (X2) dan kepuasan konsumen semakin besar nilai harga semakin meningkat kepuasan konsumen. Koefisien regresi variabel harga (X2) sebesar 0,233 Artinya jika variabel lain nilainya tetap dan variabel harga (X2) mengalami kenaikan 1 satuan maka kepuasan konsumen meningkat sebesar 0,233 .

b3 $=0,416$ koefisien bernilai negatif artinya terjadi hubungan negatif antara pelayanan (X3) dan kepuasan konsumen. Maka 
semakin besar nilai pelayanan semakin menurun kepuasan konsumen . koefisien regresi variabel pelayanan (X3) sebesar 0,416 . Artinya jika variabel lain nilainya tetap dan variabel pelayanan (X3) naik 1 satuan maka kepuasan konsumen menurun 0,416 .

b. Analisis Regresi Berganda Model 2

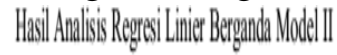

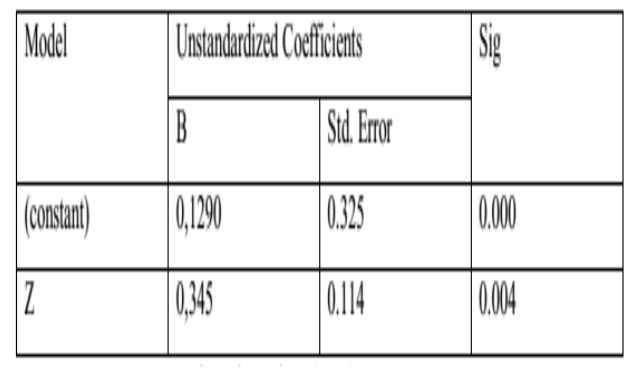

$\mathrm{Y}=\mathrm{a}+\mathrm{bZ}+\mathrm{e}$

Diketahui :

$\mathrm{Y}=0,1290+0,345 \mathrm{Z}+\mathrm{e}$

Dari hasil persamaan regresi linier berganda tersebut, dapat diinteprestasikan sebagai berikut: $\mathrm{a}=0,1290$ ialah nilai konstanta. Jika nilai $\mathrm{X} 4$ dimisalkan 0 maka nilai dari loyalitas konsumen akan meningkat sebesar 0,1290.

$b=0,345$ koefisien bernilai positif artinya terjadi hubungan positif antara kepuasankonsumen (Z) dan loyalitas konsumen semakain besar kepuasan konsumen (Z) semakin meningkat loyalitas konsumen. Koefisien regresi variabel kepuasan konsumen (Z) sebesar 0,345. Artinya jika varabel lain nilainya tetap dan variabel kepuasan (Z) naik 1 satuan maka loyalitas konsumen meningkat 0,345 .
4. Hasil Uji Parsial (Uji T)

a. Uji Parsial Model 1

Uji $t$ pada model I ini bertujuan untuk mengetahui seberapa besar atau signifikan pengaruh variabel bebas yaitu kualitas produk (X1), harga (X2), pelayanan (X3) secara parsial atau individu terhadap variabel terikat yaitu Z (kepuasan).

Hasil Uji Signifikansi Model I

\begin{tabular}{|l|l|l|l|l|}
\hline Variabel & Unstandardized & thitung & Hasil uji & Keterangan \\
\hline Coeficients & & signifikansi & \\
\hline (constanta) & 0,677 & 3,144 & 0,003 & Signifikan \\
\hline Kualitas & 0,156 & 2,208 & 0,031 & Signifikan \\
\hline Produk (X1) & & & & \\
\hline Harga (X2) & 0,233 & 2,471 & 0,016 & Signifikan \\
\hline Pelayanan (X3) & 0,416 & 4,106 & 0,000 & Signifikan \\
\hline
\end{tabular}

Berdasarkan nilai signifikansi yang dihasilkan uji secara parsial dapat dijelaskan sebagai berikut:

1) Variabel kualitas produk (X1)

H0: kualitas produk tidak berpengaruh positif secara parsial terhadap kepuasan konsumen.

Ha: kualitas produk berperngaruh positif secara parsial terhadap kepuasan konsumen.

Jika di bandingkan antara sig.hitung variabel kualitas produk 0,031 dengan alpha 0,05. Maka 0,031 < 0,05 sehingga dapat disimpulkan bahwa hipotesis $\mathrm{Ha}$ diterima dan $\mathrm{H} 0$ ditolak, yang artinya variabel kualitas produk berpengaruh signifikan terhadap kepuasan konsumen. 
2) Variabel harga (X2)

H0: harga tidak berpengaruh positif secara parsial terhadap kepuasan konsumen.

Ha: harga berperngaruh positif secara parsial terhadap kepuasan konsumen

Jika di bandingkan antara sig.hitung variabel harga 0,016 dengan alpha 0,05. Maka 0,016 < 0,05 sehingga dapat disimpulkan bahwa hipotesis $\mathrm{H} 0$ ditolak dan $\mathrm{Ha}$ diterima, yang artinya variabel harga berpengaruh signifikan terhadap kepuasan konsumen.

3) Variabel pelayanan (X3)

$\mathrm{H} 0$ : pelayanan tidak berpengaruh positif secara parsial terhadap kepuasan konsumen.

Ha: pelayanan berperngaruh positif secara parsial terhadap kepuasan konsumen

Jika di bandingkan antara sig.hitung variabel pelayanan 0,000 dengan alpha 0,05. Maka $0,000>0,05$ sehingga dapat disimpulkan bahwa hipotesis $\mathrm{H} 0$ ditolak dan $\mathrm{Ha}$ diterima, yang artinya variabel pelayanan berpengaruh signifikan terhadap kepuasan konsumen.

b. Uji Parsial Model 2

Uji $t$ pada model II ini bertujuan untuk mengetahui seberapa besar atau signifikan pengaruh variabel kepuasan (Z) secara parsial atau individu terhadap variabel terkait yaitu Y (loyalitas konsumen).
Hasil Lji Siginifikansi Model II

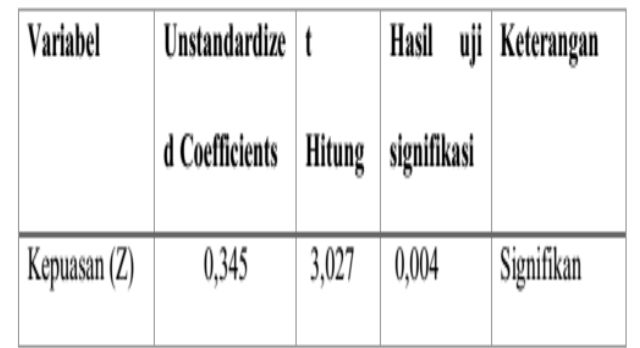

Berdasarkan nilai signifikan yang dihasilkan uji secara parsial dapat dijelaskan bahwa jika dibandingkan antara sig. hitung variabel kepuasan konsumen sebesar 0,004 dengan alpha 0,05. Maka $0,004<0,05$. Maka dari hipotesis yang ada yaitu:

H0: kepuasan konsumen tidak berpengaruh positif secara parsial terhadap loyalitas konsumen

Ha: kepuasan konsumen berpengaruh positif secara parsial terhadap loyalitas konsumen.

Maka dapat disimpulkan bahwa hipotesis H0 ditolak dan Ha diterima, yang artinya variabel kepuasan konsumen berpengaruh signifikan terhadap loyalitas konsumen.

5. Hasil Uji Koefisien Determinasi Hasil Uji Regresi (Koefisien Determinasi)

\begin{tabular}{|l|c|}
\hline Model & $\begin{array}{l}\text { Adjusted } \\
\text { Square }\end{array}$ \\
\hline $\mathbf{1}$ & 0,672 \\
\hline II & 0,118 \\
\hline & ${ }^{-} \quad$. \\
Daril & tersebut $\quad$ dapat
\end{tabular}
diambil kesimpulan bahwa pada model $\mathrm{I}$ nilai adjusted $\mathrm{R}$ square sebesar 0,672 atau 67,2\% mampu menjelaskan variabel kualitas produk (X1), harga (X2), pelayanan (X3) terhadap variabel kepuasan konsumen 
(Z), dan sisanya sebesar $32,8 \%$ dipengaruhi oleh variabel lain yang tidak terdapat dalam penelitian. Sedangkan pada model II nilai adjuste $\mathrm{R}$ square sebesar 0,118 atau $11,8 \%$ mampu menjelaskan variabel kepuasan (Z) terhadap variabel loyalitas konsumen (Y), dan sisanya sebesar $88,2 \%$ dipengaruhi oleh variabel lain yang tidak terdapat dalam penelitian.

\section{Pembahasan}

1. Pernyataan hipotesis pertama yaitu kualits produk (X1) berpengaruh positif terhadap kepuasan konsumen Outlet Biru Yogyakarta.

Hal ini dibuktikan dengan adanya nilai signifikansi $0,031<$ 0,05 dengan nilai koefisien regresi sebesar 0,156. Sehingga dapat disimpulkan bahwa variabel kualitas produk (X1) berpengaruh terhadap kepuasan konsumen Outlet biru Yogyakarta Hal ini menunjukan ada kecenderungan dimana ketika konsumen merasa kualitas produk yang dijual memiliki kualitas yang bagus maka akan sangat berpengaruh pada kepuasan yang dirasakan konsumen.

2. Pernyataan hipotesis yang kedua yaitu harga (X2) berpengaruh positif terhadap kepuasan konsumen Outlet biru Yogyakarta.

Hal ini sesuai dibuktikan dengan adanya nilai signifikansi sebesar $0,016<0,05$ dengan nilai koefiensi regresi sebesar 0,233. Sehingga dapat disimpulkan bahwa variabel harga (X2) berpengaruh terhadap kepuasan konsumen Outlet biru Yogyakarta. Artinya hal ini menunjukan bahwa harga sangat berpengaruh terhadap kepuasan konsumen.
3. Pernyataan hipotesis yang ketiga yaitu pelayanan (X3) berpengaruh positif terhadap kepuasan konsumen Outlet biru Yogyakarta.

Hal ini sesuai dibuktikan dengan adanya nilai signifikansi sebesar $0,000<0,05$ dengan nilai koefisien regresi sebesar 0,416. Sehingga dapat disimpulkan bahwa variabel pelayanan (X3) berpengaruh terhadap kepuasan konsumen Outlet biru Yogyakarta. Artinya jika pelayanan yang baik sudah dilakukan oleh karyawan maka akan memberikan efek atau dampak kepuasan yang dirasakan oleh konsumen.

4. Pernyataan hipotesis yang keempat yaitu kepuasan (Z) berpengaruh positif terhadap loyalitas pelanggan Outlet biru Yogyakarta.

Hal ini sesuai dibuktikan dengan adanya nilai signifikansi sebesar $0,004<0,05$ dengan nilai koefisien regresi sebesar 0,345. Sehingga dapat disimpulkan bahwa variabel kepuasan (Z) berpengaruh terhadap loyalitas pelanggan Outlet biru Yogyakarta Artinya jika konsumen merasa puas terhadap produk dan pelayanan di toko Outlet Biru Yogyakarta maka konsumen akan loyal untuk melakukan pembelian ulang ditoko Outlet Biru.

\section{KESIMPULAN DAN SARAN}

\section{Kesimpulan}

Berdasarkan hasil penelitian yang ada peneliti dapat mengambil kesimpulan sebagai berikut:

1. Kualitas produk berpengaruh positif terhadap kepuasan konsumen toko Outlet Biru Yogyakarta.

2. Harga berpengaruh positif terhadap kepuasan konsumen toko Outlet Biru Yogyakarta. 
3. Pelayanan berpengaruh positif terhadap kepuasan konsumen toko Outlet Biru Yogyakarta.

4. Kepuasan konsumen berpengaruh positif terhadap loyalitas pelanggan toko Outlet Biru Yogyakarta

\section{Saran}

1. Saran penelitian bagi pelayanan toko Outlet Biru :

a. Hasil penelitian menunjukan bahwa hanya kualitas produk dan harga yang berpengaruh kepada kepuasan konsumen. Variabel pelayanan tidak berpengaruh terhadap kepuasan konsumen. Namun, hal ini harus tetap ada dalam toko Outlet Biru karena pelayanan itulah yang akan membantu konsumenn dalam mencari produk yang akan di beli dan pelayanan yang dilakukan oleh kariawan itu sendiri sangat di perhatikan karna berinteraksi secara langssung kepada konsmen.

b. Penelitian ini juga memberikan informasi kepada toko Outlet Biru Yogyakarta yang mana untuk mendapatkan konsumen yang loyal maka harus diperhatikan juga kepuasan dari konsumen tersebut. Dalam penelitian ini variabel mediasi yaitu kepuasan konsumen tidak berhasil memediasi variabel loyallitas dan diharapkan pada toko Outlet Biru Yogyakarta agar lebih memberikan pelayanan yang lebih berkualitas agar tercipta kepuasan konsumen yang tentu akan berdampak pada loyalitas konsumen pada toko Outlet Biru Yogyakarta.

c. Penelitian mengenai kualitas produk, harga dan pelaynanan ini juga dapat menjadi data yang bisa digunakan perusahaan dalam membandingkan harapan dan persepsi pelanggan, atau hasil yang didapat kualiltas layanan toko Outlet Biru Yogyakarta.

2. Saran bagi peneliti selanjutnya:

a. Bagi peneliti yang akan datang sebaiknya menggunakan sampel dengan jumlah yang lebih banyak dengan alasan semakin banyak sampel semakin banyak pula data yang didapat dan semakin meyakinkan hasil dari penelitian.

b. Penelitian dimasa depan sebaiknya dapat memperluas variabel-variabel yang ada dalam penelitian selain dari kualitas produk, harga, pelayanan, kepuasan dan loyalitas konsumen yang diharapkan bisa memberi manfaat lebih luas.

\section{DAFTAR PUSTAKA}

Amanah, Dita. (2010). Pengaruh Harga dan Kualitas Produk terhadap Kepuasan Konsumen pada Majestyk Bakery dan Cake Shop cabang H.M Medan. Jurnal Keuangan dan Bisnis (Maret), hal. 71-87.

Nurani, Indah. (2018). Analisis Pengaruh Keberagaman Produk, Harga, Lokasi dan Promosi terhadap Minat Beli pada Toko Sakola Yogyakarta. Skripsi. Yogyakarta: Universitas Ahmad Dahlan.

Olson, J.P. (2013). Perilaku Konsumen dan Strategi Pemasaran. Jakarta: Salemba Empat.

Saidani, Basrah, dan Samsul Arifi. (2012). Pengaruh Kualitas Produk dan Kualitas Layanan Terhadap Kepuasan Konsumen dan Minat Beli Pada Ranch Market. Jurnal Riset Manajemen Sains Indonesia (Maret), hal. 1-22. 
Saputro, Hendry Dwi. (2013).

Membangun Loyalitas Pelanggan melalui Kualitas Produk, Harga,

dan Pelayanan pada Toko

Bangunan Indah Kiat Gemilang di

Kudus. Jurnal Ekonomi dan Bisnis

Indonesia (Maret), hal.1-10.

Sugiyono. (2010). Metode Penelitian

Bisnis. Bandung: Alfabeta

Sugiyono. (2014). Metode Penelitian

Bisnis. Bandung: Alfabeta. 